\title{
Relationship Between Cytomegalovirus Infection and Steroid Resistance in Inflammatory Bowel Disease: A Meta-Analysis
}

\author{
Xiao-wei $\mathrm{Wu}^{1} \cdot$ Lin $\mathrm{Wu}^{1} \cdot$ Hong-zan $\mathrm{Ji}^{1} \cdot$ Fang-yu Wang ${ }^{1}$
}

Received: 29 September 2014/ Accepted: 24 May 2015/Published online: 2 June 2015

(C) The Author(s) 2015. This article is published with open access at Springerlink.com

\begin{abstract}
Background and Aims Steroid resistance presents an administration difficulty in inflammatory bowel disease (IBD). The reason of steroid resistance is still unclear, but cytomegalovirus (CMV) infection may be a potential cause in some IBD patients. We carried out a meta-analysis to investigate the relationship between CMV infection and steroid-resistant IBD.

Methods The PubMed, EMBASE, and Cochrane Library databases were searched up to June 2014, with no language restrictions, for observational studies. Additional references were obtained from reviewed articles.

Results Eleven studies involving 867 IBD patients were included in the meta-analysis. Steroid resistance rate was $70.0 \%$ in CMV-positive IBD patients, which was significantly higher than that in CMV-negative IBD patients $(\mathrm{RR}=2.12,95 \% \mathrm{CI}=1.72-2.61)$. There was significant heterogeneity in the included eleven studies $\left(I^{2}=57.6 \%\right)$. When the only one study with a few patients was excluded, sensitivity analysis suggested a similar outcome $(\mathrm{RR}=2.07,95 \% \mathrm{CI}=1.80-2.39,10$ studies). Based on the funnel plot and Egger's test, we considered that there was a probable publication bias.
\end{abstract}

Xiao-Wei Wu and Lin Wu have contributed equally to this article.

Fang-yu Wang

Wangfangyu2014@126.com

1 Department of Gastroenterology and Hepatology, Jinling Hospital, Medical School of Nanjing University, No. 305 Zhongshan East Road, Nanjing 210002, Jiangsu Province, China
Conclusion Our meta-analysis suggests that CMV-positive IBD patients have a nearly double risk of steroid resistance compared with CMV-negative IBD patients, indicating that CMV infection is a probable cause of steroid-resistant IBD.

Keywords Cytomegalovirus - Inflammatory bowel disease · Crohn's disease - Ulcerative colitis .

Meta-analysis

\section{Introduction}

Inflammatory bowel disease (IBD) is described by chronic inflammation of the gastrointestinal tract in genetically susceptible individuals exposed to environmental risk factors, which is represented with active and quiescent phases alternating and leads to an increasing worldwide health burden [1, 2]. Crohn's disease (CD) and ulcerative colitis (UC) are well known as the two primary subtypes of IBD. These diseases may result in intestinal destructions, complications, and operative interventions [3, 4].

There is still no completely effective medicine for the treatment of IBD. 5-aminosalicylates are generally the firstline medical therapy for UC. Although most IBD patients can obtain remission by 5 -aminosalicylates and steroids administration, approximately $16-30 \%$ of UC patients and $16-20 \%$ of CD patients are resistant to steroids [5-8], and steroid-resistant patients may receive anti-TNF therapy or surgery.

The accurate mechanism of steroid resistance in IBD patients remains unclear. It is known that immunological dysfunction of the host, which can be induced by various pathogens, plays a key role in the development of IBD. Cytomegalovirus (CMV) is a member of the human 
Herpesviridae family which contains a double-stranded DNA. CMV can intrude various tissues and organs of the host, particularly the epithelium of glands and cavities. Patients with IBD are inclined to have increased risk of CMV infection [9, 10]. However, the influence of CMV infection on the prognosis of IBD patients is unclear. Some studies have showed that anti-CMV treatment can improve the condition of patients with steroid-resistant IBD [11, 12 ], but some other trails suggested that antiviral therapy is not necessary or effective [13-15]. It is still controversial about whether CMV infection can cause steroid resistance in IBD patients. For this reason, we performed a metaanalysis to further investigate the association between CMV infection and steroid-resistant IBD patients.

\section{Methods}

\section{Inclusion/Exclusion Criteria}

Studies in line with the following criteria were included: (a) investigated the prevalence of CMV infection in IBD patients; (b) presented the outcome of steroid treatment; and (c) included a control group. Studies were excluded if: (a) they used data from a previously published study; (b) they included patients are under 18 years and pregnant; and (c) they are case reports or case series.

\section{Search Strategy}

We performed a search of the PubMed, EMBASE, and Cochrane Library up to June 2014. A search strategy was constructed by using a combination of the following words: (cytomegalovirus or CMV) and (IBD or ulcerative colitis or Crohn's disease). Articles published in any language were included. A manual search of the references listed by studies retrieved from the online databases and from previously published systematic reviews was also performed to identify further relevant studies.

\section{Data Extraction}

Two investigators (XW Wu and $\mathrm{L} \mathrm{Wu}$ ) extracted data. Any differences about study inclusion, data extraction, and interpretation were resolved by consensus before the final analysis. Study variables were gathered in the following categories: the year of publication, the country of origin, the study center, the characteristics of patients, CMV detection method, and definitions of steroid resistance. To avoid the inclusion of duplicated data in final analysis, retrieved studies were carefully evaluated and checked by comparison of author names, geographical locations, and period of study.

\section{Statistical Methods}

Meta-analysis was carried out by combining the risk ratio (RR) between the CMV-positive groups and CMV-negative groups of the individual studies in a global RR. Statistical heterogeneity test was performed by using the Chisquare and $I^{2}$ statistics, and $I^{2}$ value of more than $50 \%$ was considered to have substantial heterogeneity [16]. A random-effects model was selected when the heterogeneity test showed $I^{2}$ value of more than $50 \%$; otherwise, a fixedeffects model was used. Funnel plot was used as an indicator of publication bias [17]. The Stata version 12.0 software (Stata Corporation, College Station, TX, USA) was used for all data analysis.

\section{Results}

\section{Search Results}

Our search identified 431 potentially relevant studies, of which 398 were excluded after title and abstract screening. Thirty-three articles were retained for full-text review. Seven review articles, four case reports, eight studies without outcome of steroid treatment, and three studies with incomplete data were excluded subsequently. Finally, we identified eleven studies that fulfilled the inclusion criteria [12, 18-27]. These studies included a total of 867 cases of IBD. Figure 1 shows the study flow diagram.

\section{Characteristics of Included Studies}

The characteristics of included studies and patients are presented in Table 1. Four studies came from Asia, four

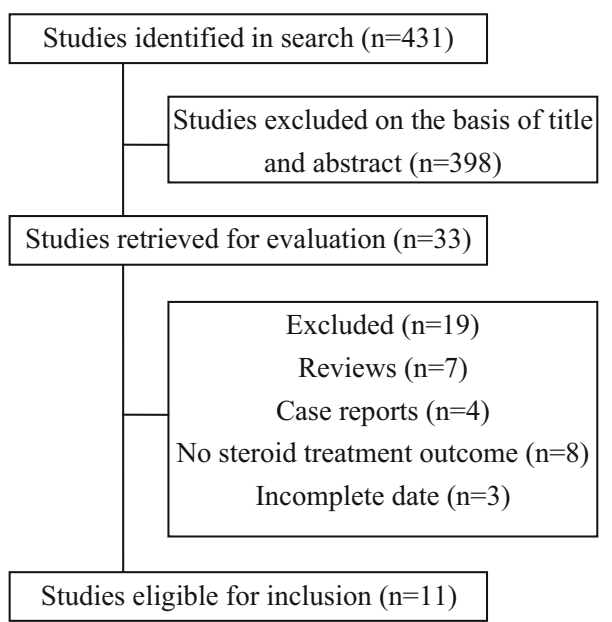

Fig. 1 Flow diagram of the study selection process 
Table 1 Characteristics of the studies included in the meta-analysis

\begin{tabular}{|c|c|c|c|c|c|c|c|c|c|c|}
\hline Study & Country & $\begin{array}{l}\text { Study } \\
\text { type }\end{array}$ & $\begin{array}{l}\text { Study } \\
\text { site }\end{array}$ & $\begin{array}{l}\text { Mean } \\
\text { age }\end{array}$ & $\begin{array}{l}\text { Male } \\
(\%)\end{array}$ & $\begin{array}{l}\text { IBD } \\
\text { subtype }\end{array}$ & $\begin{array}{l}\mathrm{N} \\
(\mathrm{CMV}+)\end{array}$ & $\begin{array}{l}\mathrm{N} \\
(\mathrm{CMV}-)\end{array}$ & CMV detection & Definition of steroid resistance \\
\hline$[18]$ & Japan & $\mathrm{P}$ & $\mathrm{S}$ & 39 & 40 & $\mathrm{UC}$ & 16 & 31 & $\begin{array}{l}\text { Serology, } \\
\text { histopathology }\end{array}$ & $\begin{array}{l}\text { No tendency to improvement even } \\
\text { when prednisone was administered } \\
\text { at a daily dose of } 30 \mathrm{mg} \text { or more } \\
\text { for at least } 2 \text { weeks }\end{array}$ \\
\hline$[20]$ & USA & $\mathrm{R}$ & $\mathrm{S}$ & 37 & NR & $\mathrm{UC}$ & 11 & 69 & Histopathology & $\begin{array}{l}\text { Absence of response to systemic } \\
\text { steroids administered for a period } \\
\text { of } 2 \text { or more weeks }\end{array}$ \\
\hline [19] & Italy & $\mathrm{R}$ & $\mathrm{S}$ & NR & 55 & $\mathrm{UC} / \mathrm{CD}$ & 9 & 33 & $\begin{array}{l}\text { Serology, } \\
\text { histopathology }\end{array}$ & $\begin{array}{l}\text { Persistent symptoms despite } \\
\text { methylprednisolone } 1 \mathrm{mg} / \mathrm{kg} / \mathrm{die} \\
\text { i.v. for } 5-10 \text { days }\end{array}$ \\
\hline$[21]$ & Italy & $\mathrm{P}$ & $\mathrm{S}$ & 44.9 & 43 & $\mathrm{UC}$ & 17 & 60 & Histopathology & $\begin{array}{l}\text { Chronically active UC with poor } \\
\text { response to medium-high dose of } \\
\text { steroids for more than } 2 \text { weeks }\end{array}$ \\
\hline$[22]$ & Japan & $\mathrm{R}$ & $\mathrm{S}$ & 33 & NR & UC & 14 & 8 & Histopathology & $\begin{array}{l}\text { Patients showing no tendency towarc } \\
\text { improvement, even when } \\
\text { prednisolone was administered at } \\
\text { daily dose of } 30 \mathrm{mg} \text { or more for a } \\
\text { least } 2 \text { weeks }\end{array}$ \\
\hline [24] & Egypt & $\mathrm{P}$ & $\mathrm{S}$ & 37 & 43 & $\mathrm{UC} / \mathrm{CD}$ & 9 & 45 & $\begin{array}{l}\text { Serology, } \\
\text { histopathology }\end{array}$ & NR \\
\hline$[23]$ & China & $\mathrm{R}$ & $\mathrm{S}$ & 44.5 & 50 & $\mathrm{UC}$ & 11 & 65 & Histopathology & $\begin{array}{l}\text { Resistant to intravenous } \\
\text { hydrocortisone } 100 \mathrm{mg} \text { three times } \\
\text { daily for 5-7 days }\end{array}$ \\
\hline [26] & France & $\mathrm{P}$ & $\mathrm{S}$ & 43.6 & 90 & UC & 16 & 26 & $\begin{array}{l}\text { Histopathology, } \\
\text { PCR }\end{array}$ & $\begin{array}{l}\text { Persistence of a Lichtiger score } \\
\text { above } 7 \text { for moderate UC and } \\
\text { Lichtiger Index score } \geq 10 \text { and/or a } \\
\text { decrease }<3 \text { for severe UC } \\
\text { (corticosteroids administered at a } \\
\text { dose of } 1 \mathrm{mg} / \mathrm{kg} \text { for } 7 \text { days) }\end{array}$ \\
\hline [25] & Italy & $\mathrm{P}$ & $\mathrm{S}$ & NR & 59 & $\mathrm{UC}$ & 28 & 57 & $\begin{array}{l}\text { Histopathology, } \\
\text { PCR }\end{array}$ & NR \\
\hline [12] & Korea & $\mathrm{P}$ & M & 43 & 67 & $\mathrm{UC}$ & 31 & 41 & $\begin{array}{l}\text { Serology, } \\
\text { histopathology }\end{array}$ & $\begin{array}{l}\text { Absence of clinical improvement } \\
\text { after a 7- to 14-day course of } \\
\text { intravenous steroid administration }\end{array}$ \\
\hline [27] & USA & $\mathrm{R}$ & $\mathrm{S}$ & NR & 37 & $\mathrm{UC} / \mathrm{CD}$ & 68 & 202 & Histopathology & $\begin{array}{l}\text { Minimal or no improvement in } \\
\text { symptoms after } 14 \text { days of oral } \\
\text { corticosteroids, } 7 \text { days of } \\
\text { intravenous corticosteroids }\end{array}$ \\
\hline
\end{tabular}

$P$ prospective, $R$ retrospective, $S$ single center, $M$ multicenter, $I B D$ inflammatory bowel disease, $U C$ ulcerative colitis, $C D$ Crohn's disease, $N R$ not reported

studies came from Europe, two studies came from America, and one study came from Africa. Ten of them were single-center studies, and only one was multicenter study. The mean age of IBD patients ranged from 33 to 44.9 years. Five studies used histopathological tests, four studies used a combination of serologic and histopathological tests, and two studies used a combination of PCR and histopathological tests.

\section{Infection and Steroid-Resistant IBD}

When involving all studies including 867 IBD patients, a total of $70.0 \%$ of patients in the CMV-positive groups were observed with steroid resistance, compared with $34.5 \%$ of patients in the CMV-negative groups. The pooled RR of steroid resistance rate in CMV-positive groups compared to CMV-negative groups was $2.12(95 \% \mathrm{CI}=1.72-2.61$, 


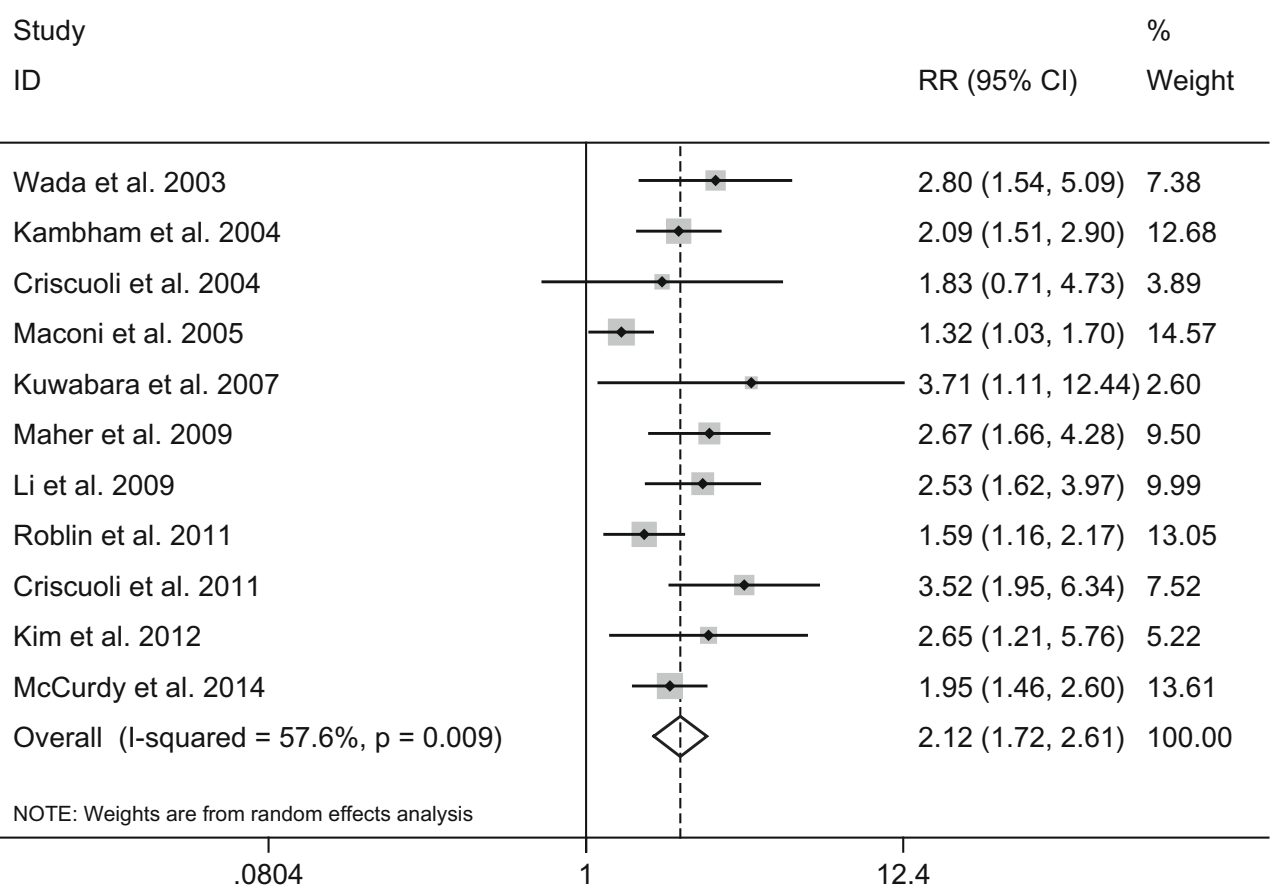

Fig. 2 Forest plot of steroid resistance rate in CMV-positive groups versus CMV-negative groups

Table 2 Subgroup analyses of pooled relative risks

\begin{tabular}{|c|c|c|c|c|c|c|}
\hline Characteristics & Subgroup & $\mathrm{N}$ (Study) & N (Subject) & $\mathrm{RR}$ & $95 \% \mathrm{CI}$ & $\mathrm{I} 2(\%)$ \\
\hline All & & 11 & 867 & 2.12 & $1.72-2.61$ & 58 \\
\hline \multirow[t]{2}{*}{ Race of subjects } & White & 7 & 650 & 1.94 & $1.52-2.47$ & 64 \\
\hline & Yellow & 4 & 217 & 2.79 & $1.96-3.97$ & 0 \\
\hline \multirow[t]{3}{*}{ CMV detection } & Histopathology & 5 & 525 & 1.93 & $1.45-2.57$ & 65 \\
\hline & Serology, histopathology & 4 & 215 & 2.56 & $1.81-3.62$ & 0 \\
\hline & Histopathology, PCR & 2 & 127 & 2.29 & $0.93-5.62$ & 86 \\
\hline \multirow[t]{3}{*}{ Steroid resistance definition } & Steroid given for $\geq 2$ weeks & 4 & 226 & 2.03 & $1.29-3.19$ & 75 \\
\hline & Steroid given for $<2$ weeks & 5 & 502 & 1.99 & $1.64-2.43$ & 0 \\
\hline & Not reported & 2 & 139 & 3.17 & $2.11-4.76$ & 0 \\
\hline
\end{tabular}

$P<0.00001)$. A random-effects model was used for the meta-analysis because there was significant heterogeneity in the included studies $\left(I^{2}=57.6 \%\right)$. The result is shown in Fig. 2.

\section{Subgroup and Sensitivity Analysis}

Subgroup analysis of studies according to race of subjects, CMV detection method, and definition of steroid resistance is summarized in Table 2. In sensitivity analysis, when the only one study with a few patients was excluded, significant association between CMV infection and steroid-resistant
IBD was found either $(\mathrm{RR}=2.07,95 \% \mathrm{CI}=1.80-2.39$, $P<0.00001,10$ studies $)$.

\section{Publication Bias}

We found that inspection of the funnel plot did not reveal a reasonably symmetrical distribution of included studies on the association between CMV infection and steroid-resistant IBD (Fig. 3). The Egger's linear regression method also suggested a statistical evidence of publication bias $(P=0.016)$. Accordingly, we considered that there was a probable bias for publication. 


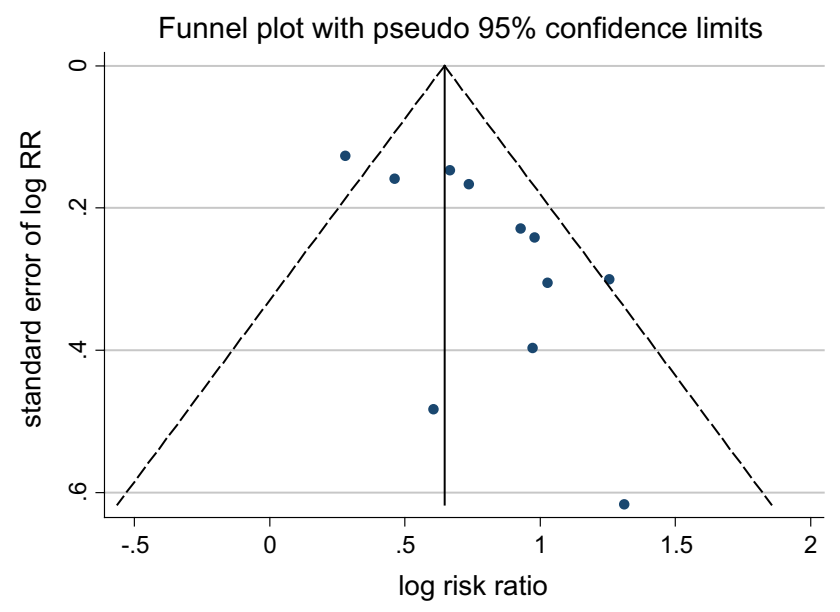

Fig. 3 Funnel plot analysis

\section{Discussion}

The relationship between CMV and IBD was first described in 1961 [28]. From that time, the real pathological and clinical consequences of CMV infection have been debated for years, and the role of CMV infection in patients with IBD is not confirmed yet. It is conflicting about whether CMV reactivation aggravates the inflammation in patients with established IBD or is merely a sequel of IBD activity [29]. A prospective study found that CMV infection was rare with a rate of $4.5 \%$ in new-onset UC patients, which suggested that immunosuppressive medications may be an important risk factor for CMV infection [30]. The existing studies are interpreted with limitation due to the retrospective design, insufficient subject, varied diagnostic methods of CMV detection, and even different classifications of disease severity. Two previous systematic reviews provided important information regarding the role of CMV in steroid-resistant IBD [31, 32]. Using strict inclusion and exclusion criteria, our analysis included five additional studies. Furthermore, we conducted forest plot and subgroup analysis to get the pooled $\mathrm{RR}$, and our results showed a positive correlation between CMV infection and steroid resistance in IBD patients.

The association between CMV infection and steroid resistance is always simply considered as a marker for higher viral reactivation rates in immunocompromised patients. But a meta-analysis involving individual patient data indicated that CMV colitis may occur in apparently immunocompetent patients [33]. Although whether CMV infection causes steroid resistance in patients with IBD is still uncertain, there are some probable mechanisms that can explain this phenomenon. CMV might induce malfunction of $\mathrm{T}$ lymphocytes and increase the secretion of interferon gamma and tumor necrosis factor alpha, which can exasperate inflammatory reaction [34]. Furthermore, CMV can induce the expression of cyclooxygenase-2 through EGFRK, Raf, MEK1/2, and ERK1/2 pathway, which plays a key role of worsening the inflammation [35].

In our meta-analysis, the pooled RR in CMV-positive groups versus CMV-negative groups was 2.12 (95\% $\mathrm{CI}=1.72-2.61$ ), which suggested that CMV infection might lead to a nearly double risk of steroid resistance in IBD patients. Although the exact direction of causal relationship between CMV and IBD is hard to establish, it is necessary to focus on the potential effect of CMV aggravating the inflammation. Furthermore, association between antiviral treatment and a favorable outcome was demonstrated in some included studies, which may enhance the evidence of CMV infection as a possible cause of steroidresistant IBD. Wada et al. [18] found that after administration of ganciclovir for 14 days, eight of the twelve UC patients infected with CMV showed resolution of symptoms and improved endoscopic features. Kim et al. [12] reported that the CMV infection was more frequent in steroid-refractory UC, and patients with CMV infection had a higher dose of steroids used during the flare-up period. Of the fourteen steroid-refractory UC patients with CMV infection, eleven patients improved with ganciclovir treatment, and only three patients underwent surgery because of a lack of response.

Our meta-analysis shows that CMV may be a probable cause of steroid-resistant IBD. However, the results of the meta-analysis are limited. Firstly, most studies are retrospective. Secondly, there have been some differences in the method of CMV detection and definition of steroid resistance. Furthermore, there may be a potential publication bias. Therefore, the finding should be interpreted cautiously, and more multicenter prospective studies are required to confirm the results of this meta-analysis.

Acknowledgments This study was funded by research Grants from the National Natural Science Foundation of China (81270453).

\section{Conflict of interest None.}

Open Access This article is distributed under the terms of the Creative Commons Attribution-NonCommercial 4.0 International License (http://creativecommons.org/licenses/by-nc/4.0/), which permits any noncommercial use, distribution, and reproduction in any medium, provided you give appropriate credit to the original author(s) and the source, provide a link to the Creative Commons license, and indicate if changes were made.

\section{References}

1. Abraham C, Cho JH. Inflammatory bowel disease. $N$ Engl J Med. 2009;361:2066-2078.

2. Nikolaus S, Schreiber S. Diagnostics of inflammatory bowel disease. Gastroenterology. 2007;133:1670-1689.

3. Larson DW, Pemberton JH. Current concepts and controversies in surgery for IBD. Gastroenterology. 2004;126:1611-1619. 
4. Podolsky DK. Inflammatory bowel disease. $N$ Engl J Med. 2002;347:417-429.

5. Moss AC, Peppercorn MA. Steroid-refractory severe ulcerative colitis: what are the available treatment options? Drugs. 2008;68: $1157-1167$

6. Truelove SC, Witts LJ. Cortisone and corticotrophin in ulcerative colitis. Br Med J. 1959;1:387-394.

7. Munkholm P, Langholz E, Davidsen M, Binder V. Frequency of glucocorticoid resistance and dependency in Crohn's disease. Gut. 1994;35:360-362.

8. Faubion WA Jr, Loftus EV Jr, Harmsen WS, Zinsmeister AR, Sandborn WJ. The natural history of corticosteroid therapy for inflammatory bowel disease: a population-based study. Gastroenterology. 2001;121:255-260.

9. Kishore J, Ghoshal U, Ghoshal UC, et al. Infection with cytomegalovirus in patients with inflammatory bowel disease: prevalence, clinical significance and outcome. J Med Microbiol. 2004;53:1155-1160.

10. Criscuoli V, Rizzuto MR, Cottone M. Cytomegalovirus and inflammatory bowel disease: is there a link? World J Gastroenterol. 2006;12:4813-4818.

11. Maconi G, Lombardini M, Furfaro F, Bezzio C, Zerbi P, Ardizzone S. Long-term outcome of inflammatory bowel diseases with cytomegalovirus colitis: effect of antiviral treatment. Eur J Gastroenterol Hepatol. 2014;26:1146-1151.

12. Kim YS, Kim YH, Kim JS, et al. The prevalence and efficacy of ganciclovir on steroid-refractory ulcerative colitis with cytomegalovirus infection: a prospective multicenter study. J Clin Gastroenterol. 2012;46:51-56.

13. Matsuoka K, Iwao Y, Mori T, et al. Cytomegalovirus is frequently reactivated and disappears without antiviral agents in ulcerative colitis patients. Am J Gastroenterol. 2007;102:331-337.

14. Zeki SS, Kodati S, Jordan A, Hansi N, Thomas-Gibson S, Nightingale JM. Colectomy rates for patients treated for CMV disease in the context of ulcerative colitis do not differ from those who are not treated for CMV disease. Gastroenterology. 2010; 138:S537.

15. Delvincourt M, Lopez A, Pillet S, et al. The impact of cytomegalovirus reactivation and its treatment on the course of inflammatory bowel disease. Aliment Pharmacol Ther. 2014;39: 712-720.

16. Higgins JP, Thompson SG, Deeks JJ, Altman DG. Measuring inconsistency in meta-analyses. BMJ. 2003;327:557-560.

17. Egger M, Davey Smith G, Schneider M, Minder C. Bias in metaanalysis detected by a simple, graphical test. BMJ. 1997;315: 629-634.

18. Wada Y, Matsui T, Matake H, et al. Intractable ulcerative colitis caused by cytomegalovirus infection: a prospective study on prevalence, diagnosis, and treatment. Dis Colon Rectum. 2003;46:S59-S65.

19. Criscuoli V, Casa A, Orlando A, et al. Severe acute colitis associated with CMV: a prevalence study. Dig Liver Dis. 2004;36: 818-820.
20. Kambham N, Vij R, Cartwright CA, Longacre T. Cytomegalovirus infection in steroid-refractory ulcerative colitis: a case-control study. Am J Surg Pathol. 2004;28:365-373.

21. Maconi G, Colombo E, Zerbi P, et al. Prevalence, detection rate and outcome of cytomegalovirus infection in ulcerative colitis patients requiring colonic resection. Dig Liver Dis. 2005;37: 418-423.

22. Kuwabara A, Okamoto H, Suda T, Ajioka Y, Hatakeyama K. Clinicopathologic characteristics of clinically relevant cytomegalovirus infection in inflammatory bowel disease. $J$ Gastroenterol. 2007;42:823-829.

23. Li TT, Lv ZS, Wang BM, Zhang J. Relationship between refractory ulcerative colitis and cytomegalovirus infection. World Chin J Dig. 2010;18:1174-1177.

24. Maher MM, Nassar MI. Acute cytomegalovirus infection is a risk factor in refractory and complicated inflammatory bowel disease. Dig Dis Sci. 2009;54:2456-2462.

25. Criscuoli V, Rizzuto MR, Montalbano L, Gallo E, Cottone M. Natural history of cytomegalovirus infection in a series of patients diagnosed with moderate-severe ulcerative colitis. World $J$ Gastroenterol. 2011;17:633-638.

26. Roblin X, Pillet S, Oussalah A, et al. Cytomegalovirus load in inflamed intestinal tissue is predictive of resistance to immunosuppressive therapy in ulcerative colitis. Am J Gastroenterol. 2011;106:2001-2008.

27. McCurdy JD, Jones A, Enders FT, et al. A model for identifying cytomegalovirus in patients with inflammatory bowel disease. Clin Gastroenterol Hepatol. 2015;13:131-137.

28. Powell RD, Warner NE, Levine RS, Kirsner JB. Cytomegalic inclusion disease and ulcerative colitis; report of a case in a young adult. Am J Med. 1961;30:334-340.

29. Lawlor G, Moss AC. Cytomegalovirus in inflammatory bowel disease: pathogen or innocent bystander? Inflamm Bowel Dis. 2010;16:1620-1627.

30. Kim YS, Kim YH, Kim JS, et al. Cytomegalovirus infection in patients with new onset ulcerative colitis: a prospective study. Hepatogastroenterology. 2012;59:1098-1101.

31. Ayre K, Warren BF, Jeffery K, Travis SP. The role of CMV in steroid-resistant ulcerative colitis: a systematic review. J Crohns Colitis. 2009;3:141-148.

32. Hommes DW, Sterringa G, van Deventer SJ, Tytgat GN, Weel J. The pathogenicity of cytomegalovirus in inflammatory bowel disease: a systematic review and evidence-based recommendations for future research. Inflamm Bowel Dis. 2004;10:245-250.

33. Galiatsatos P, Shrier I, Lamoureux E, Szilagyi A. Meta-analysis of outcome of cytomegalovirus colitis in immunocompetent hosts. Dig Dis Sci. 2005;50:609-616.

34. van Leeuwen EM, Remmerswaal EB, Vossen MT, et al. Emergence of a $\mathrm{CD} 4+\mathrm{CD} 28$ - granzyme $\mathrm{B}+$, cytomegalovirusspecific $\mathrm{T}$ cell subset after recovery of primary cytomegalovirus infection. J Immunol. 2004;173:1834-1841.

35. Yi HA, Kim MS, Jang SY, Lee YM, Ahn JH, Lee CH. Cellular signals involved in cyclooxygenase-2 expression induced by human cytomegalovirus. Virus Res. 2009;146:89-96. 